\title{
Integrating Service Learning and Digital Technologies: Examining the Challenge and the Promise
}

\section{(Integrando aprendizaje-servicio y tecnologías digitales: análisis de sus desafíos y promesas)}

\author{
Robert G. Bringle \\ Patti H. Clayton \\ Indiana University Purdue University Indianapolis (United States)
}

DOI: http://dx.doi.org/10.5944/ried.23.1.25386

\section{How to reference this article:}

Bringle, R. G., \& Clayton, P. H. (2020). Integrating Service Learning and Digital Technologies: Examining the Challenge and the Promise. RIED. Revista Iberoamericana de Educación a Distancia, 23(1), pp. 43-65. doi: http://dx.doi. org/10.5944/ried.23.1.25386

\begin{abstract}
Our intent is to frame the integration of service learning and digital technologies broadly in teaching and learning and to explore some of the complexities of the challenge and the promise, thereby setting up readers' engagement with the questions and issues that follow in the papers of RIED. We seek to provide perspectives that may contribute to subsequent implementation of pedagogical innovations and research that will improve practice and, in turn outcomes for all. We begin by offering an overview of the what's and why's of service learning. We then examine some of the how's of service learning in the context of its integration with digital technologies. Finally, we explore several issues that may shape new developments at the interface of these two pedagogical innovations.
\end{abstract}

Keywords: service learning; digital technologies; distance education; civic education.

\section{Resumen}

En este artículo pretendemos enmarcar la incorporación del aprendizaje-servicio y las tecnologías digitales en la enseñanza y el aprendizaje, a la vez que analizar la complejidad de algunos de sus desafíos y promesas. De esta forma, se compromete a los lectores con las preguntas y los problemas que se abordan en los artículos que componen este monográfico 
de RIED. Buscamos proporcionar perspectivas que puedan contribuir a la implementación de innovaciones e investigaciones pedagógicas que mejorarán la práctica y, en consecuencia, los resultados de aprendizaje. Comenzamos brindando una descripción general de lo qué es y el porqué del aprendizaje-servicio, para examinar, en una segunda parte, el cómo del aprendizaje-servicio en escenarios digitales. Finalmente, exploramos varios temas que pueden dar forma a nuevos desarrollos en el contexto de estas < dos innovaciones pedagógicas.

Palabras clave: aprendizaje-servicio; tecnologías digitales; educación a distancia; educación cívica.

United Nations Special Rapporteur Kishore Singh's (2016) report on education in the digital age provides a jumping off point for this special issue of Revista Iberoamericana de Educación a Distancia (RIED) and for our introductory article. The central question in this report is "how to uphold the norms and principles that underlie the right to education while embracing digital technologies, which are revolutionizing teaching and learning processes and transforming the landscape of higher education" (para 1). Singh (2016) noted that,

The 1998 World Declaration on Higher Education for the Twenty-First Century: Vision and Action ... called upon higher education institutions to give the opportunity to students to fully develop their own abilities with a sense of social responsibility, educating them to become full participants in democratic society and promoters of changes that will foster equity and justice. (para 109)

This report nicely frames this special issue by exploring the use of digital technologies in education ${ }^{1}$ to advance not only student learning but also broader public purposes. The public purposes of the academy are increasingly of interest across higher education institutions around the world and are often pursued through the pedagogy of service learning (Aramburuzabala, McIlrath \& Opazo, 2019; Hatcher, Bringle, \& Hahn, 2017; Herrero, 2017; International Christian University, 2009; Ma \& Chan, 2013; McIlrath \& MacLabhrainn, 2007; McIlrath, Lyons, \& Munck, 2012; Saltmarsh \& Hartley, 2011; Xing \& Ma, 2010).

This special issue considers the role of service learning in the search for quality in teaching and learning that is enhanced with, supported by, or delivered through digital technologies, with a particular focus on learning related to the humanistic goals of education. Over two decades of research on the student learning outcomes of service learning has encompassed a wide range of learning domains, including:

- personal growth (e.g., self-awareness, self-efficacy, identity development, spirituality, leadership development, moral development; see Brandenberger, 2013 for an overview), 
- intercultural competence (e.g., respect, curiosity, sociolinguistic awareness, listening, empathy, ethnorelative perspective; see Deardorff \& Edwards, 2013 for an overview),

- civic outcomes (e.g., communication, collaboration, public problem solving, knowledge of community history and public processes, organizational analysis; see Battistoni, 2013 for an overview),

- academic learning (e.g., knowledge and application of concepts and theories, thinking from disciplinary/interdisciplinary perspectives; see Jameson, Clayton, \& Ash, 2013 for an overview),

- cognitive skills (e.g., critical thinking, intellectual development, metacognition, transfer; see Fitch, Steinke, \& Hudson, 2013 for an overview).

Some of this research has been evaluated in meta-analyses (Celio, Durlak, \& Dymnicki, 2011; Conway, Amel, \& Gerwien, 2009; Novak, Markey, \& Allen, 2007; Warren, 2012; Yorio \& Ye, 2012). Taken together this extensive body of work confirms the contributions well-designed service learning can make to multiple domains of student learning, including those framed as humanistic.

With roots in social justice and holistic student development (Bringle, Edwards, \& Clayton, 2014; Hatcher, Bringle, \& Hahn, 2017; Saltmarsh \& Hartley, 2011; Stanton, Giles, \& Cruz, 1999; Zlotkowski \& Duffy, 2010), service learning shares many of the concerns regarding current trajectories of higher education that Singh's (2016) report suggests may characterize the incorporation of digital technologies in education: exacerbating existing social divides, conceptualizing teaching as mere transmission of information, constraining pedagogical design that is sensitive to differences among individual students and contexts, and evoking consumer-oriented narratives of education. Many service learning pracititioners' aspirations are aligned with the observations in the report that

Full development of the human personality is the primary objective of education, as laid down in international human rights conventions. The four pillars of education - learning to know, learning to do, learning to live together and learning to be propounded by the International Commission on Education for the Twenty-First Century in its 1996 report Learning: The Treasure Within, continue to be important.... Universities, as the moral seat of learning, must foster the common human values so much in need today, in the face of the challenges of globalization. Fostering the humanistic mission of education is of paramount importance to counter the trend towards the pursuit of material values and a merely instrumental role for education. This is critically important, as the humanistic mission of education is being vitiated. (para 67 and 68)

In light of this mix of concerns and possibilities, service learning provides an opportunity to partner with teaching and learning initiatives that incorporate digital technologies such that the latter better fulfills Singh's (2016) vision: 
the use of digital technologies in education must ... increase access, not limit it. It must promote equity, not exacerbate existing disparities in society. It must eliminate discrimination, not create new barriers. It must improve the quality of education, not undermine it.... The use of information and communications technologies should not be detrimental to the social function of universities or undermine their core mission as the moral seat of learning. (pp. 100 and 105).

With regard to this last statement, we posit that the integration of service learning with digital technologies can broaden, deepen, and integrate civic and humanistic outcomes in learners' developmental pathways, which includes instructors, staff, and institutions of higher education as well as members of broader communities in being and becoming those "full participants in democratic society and promoters of changes that will foster equity and justice" called for by the global community 20 years ago (as noted above).

Given this goal and because of the fast pace of the changes digital technologies are bringing to higher education, it is imperative that educators consider -- as the contributors to this special issue do -- the relationships between the use of digital technologies in higher education, on the one hand, and pedagogies such as service learning, on the other. Service learning aspires for all participants, including but not limited to students, to grow and to support one another's growth, not only as learners and professionals but also as both contributing members of local and global communities who share responsibility for their world and human beings who learn, work, create, and play throughout each phase of their lives. How can digital technologies enhance service learning's ability to fulfill this promise? How can what has been learned over the past decades of service learning practice and research inform the development of technology-enhanced learning, especially in the direction of civic and humanistic goals? What new possibilities might emerge synergistically through the integration of the best that service learning and digital technology each has to offer, and what pitfalls exist? Most fundamentally, how can this integration fully leverage what the editors call the "challenge of humanization of virtual learning scenarios": the search for ways of transmitting common human values in an increasingly globalized and technological world, the growth of our capacities to organize and relate to others through more than materialistic and transactional means, and the widespread development of commitment to contribute to the public good through civic thought and action?

Our intent is to frame the integration of service learning and digital technologies broadlyinteaching andlearning and to exploresomeofthecomplexities of the challenge and the promise, thereby setting up readers' engagement with the questions and issues that follow in the papers in this issue of RIED. We seek to provide perspectives that may contribute to subsequent implementation of pedagogical innovations and research that will improve practice and outcomes for all. We commence by providing an overview of the what's and why's of service learning. We then examine some of the how's of service learning in the context of its integration with digital technologies. 
Finally, we explore several issues that may shape new developments at the interface of these two pedagogical innovations. Throughout, we bring to bear thinking and practice from Iberoamerica and Europe as well as from the United States, which is our primary context. We acknowledge that educators around the world use different frameworks and terminology (Aramburuzabala, Vargas-Moniz, Opazo, McIlrath, \& Stark, 2019), which can limit shared vocabulary and inhibit dialogue, particularly when terms are translated without carry-over of their nuances and connotations. We do not wish to impose any particular terminology on others, but we will use terminology that is familiar to us; we invite readers to make appropriate adjustments to the language used here for their context and practice.

\section{SERVICE LEARNING}

After more than five decades of practice in the United States and a somewhat shorter history worldwide, we are confident in positing something of a consensus in understanding what service learning is for many practitioners. Both as a pedagogy and as a change strategy, service learning engages students, community members, and instructors/staff in co-creating partnerships that achieve academic, civic, and personal growth learning goals as well as advance public purposes through integrating bodies of thought (often, the content of a course) with critical reflection on collaborative action that enhances the quality of life (often, through movement toward justice). We do not suggest a one size fits all approach to the pedagogy; indeed, customized design to a particular context -- the place, the people, the specific opportunities and constraints, the built and natural environment, the history, the culture -- is essential (Aramburuzabala et al., 2019; Siemers, Harrison, Clayton, \& Stanley, 2015; Stokamer \& Clayton, 2017). Thus, we agree with Furco and Norvell (2019) that "while there are fundamental definitions, elements, and principles of service learning that apply no matter what the situation or context, the cultural fibre of the societies in which SL is practised will ultimately shape the overall character of the SL experience" (p. 32).

Europe Engage, a three-year project started in 2015 that involved primarily 12 European Union universities, focused on stimulating interest in and understanding of service learning throughout the region. Europe Engage (n.d.) defines service learning as:

An innovative pedagogical approach that integrates meaningful community service or engagement into the curriculum and offers students academic credit for the learning that derives from active engagement within community and work on a real world problem. Reflection and experiential learning strategies underpin the learning process and the service is link [sic] to the academic discipline. Service-learning brings together students, academics and the community whereby all become teaching resources, problem solvers and partners. In addition to enhancing academic and real world learning, the overall purpose of service learning is to instill in students a 
sense of civic engagement and responsibility and work towards positive social change within society. ("Our definition of service-learning")

In the European context, service learning is often considered a "mechanism" through which "to achieve the ideals associated with the democratic citizen and the promotion of active citizenship" that have become a focus and priority of higher education on the continent (McIlrath, Aramburuzabala, \& Opazo, 2019, p. 2).

Centro Latinoamericano de Aprendizaje y Servicio Solidario (CLAYSS), which is based in Argentina and facilitates regional and international service learning networks, understands service learning as

a pedagogical connection in which the educator and educated learn together from experience and together commit themselves in the transformation of reality. It implies action and reflection on the practice and establishment of ties that allow to act and to learn reciprocally with and from the community (n.d.a, para 1).

The inclusion of "solidario" (solidarity) in the name of the pedagogy "underline[s] that we are not referring to a traditional, paternalistic, occasional or superficial kind of service, but to a more horizontal bond between peoples and communities working together for the common good" (n.d. b, para 1).

Both of these definitions align well with definitions in the United States (e.g., Bringle \& Clayton, 2012; Clayton \& Kniffin, 2017; Furco, 2019) by identifying the fundamentally academic nature of service learning (vs. volunteering), the commitment to both community outcomes and student growth as community change agents, the use of reflection on experiences of working with the broader community to generate learning, the significance of personal growth and civic learning as well as academic learning and critical thinking as intentional learning goals, the central role of members of the broader community as partners (co-creators) in teaching and learning and in change-oriented work, and the centrality of working with not just in or for the community.

Of particular importance when considering the why of service learning is the emphasis on "the civic" in terms of both change in the world and learning for such change, which is echoed by Europe Engage and CLAYSS in the language (noted above) of "a sense of civic engagement and responsibility and work towards positive social change within society" and the "transformation of reality" through "ties that allow to act and to learn reciprocally with and from the community." Thus, service learning appropriately understood is not the same as problem-based learning that takes place in the community, which generally involves only the technocratic application of knowledge rather than also the transformation of knowledge and which generally lacks the integration of civic and social issues, concerns, and perspectives with academic content. 
In the United States, we often speak of civic learning -- sometimes expressed as civic outcomes, civic identity development, or civic growth -- as an essential category of the learning goals for service learning, although practice often falls short of potential. Chapters in Research on Student Civic Outcomes in Service Learning (Hatcher, Bringle, \& Hahn, 2017) explored different meanings, different measures, and different approaches to cultivating and studying civic learning in the U.S. and from several disciplinary perspectives (also see Battistoni, 2002, 2013). As Huber and Hutchings (2018) observed, integrating civic with traditional course content enriches teaching and learning: "When faculty from different disciplinary communities teach their field wearing a civic lens, both the concept of citizenship and even the field itself (as taught and learned) are subject to change" (p. x).

Emphasizing civic learning is also consistent with work by the Council of Europe, which published Competences for Democratic Culture in 2016 and which provides a framework for the civic learning domain that consists of 20 competencies focused on (a) values, (b) attitudes, (c) skills, and (d) knowledge and critical understanding. Values include human dignity, cultural diversity, democracy, and social justice. Attitudes encompass openness to cultural otherness, respect, civic-mindedness, responsibility, self-efficacy, and tolerance of ambiguity. Civic skills consist of learning, analytical and critical thinking, listening and observing, empathy, flexibility, communication, cooperation, conflict resolution. Civic knowledge and critical understanding can be of self; of language and culture; or of the world's politics, law, human rights, cultures, religions, or history. This framework can provide guidance in designing service learning for democratic citizenship, especially through the explicit incorporation of intercultural dialogue. The Council has published a second monograph on pedagogy; service learning is identified there as one of the pedagogies that can develop these competencies (Council of Europe, 2017).

These definitions implicate the centrality of civic action as both a means and a desired outcome of the educational experience. CLAYSS's emphasis on solidarity establishes a collaborative and action orientation to the civic by clarifying the kind of citizenship they seek to cultivate through service learning:

not just the knowledge of norms and values and the diagnosis of political and socioeconomic problems, but a kind of citizenship that advances in the elaboration of proposals and in the active participation of initiatives. It includes not only denunciation and complaint, but also taking responsibility and commitment in the construction of overcoming alternatives, and the work in articulation with the authorities and civil society organizations. (CLAYSS, n.d.a)

This focus on solidarity also highlights an important tension in the relationship between the conceptualization of learning goals and action (as both the stimulus to learning and the change desired in the world more generally): the degree to which the underlying framework is one of doing for others or one of doing and being with others in the context of co-creative, democratically engaged processes (Clayton \& 
Kniffin, 2017; Saltmarsh, Hartley, \& Clayton, 2009). Service learning, as understood and enacted from within the paradigm of democratic engagement (i.e., with more so than for), posits that learning and change are intertwined acts of co-creation in which all teach, learn, serve, partner, and inquire -- which is often dissonant with hierarchical, technocratic, and academic norms (Clayton et al., 2019). Stokamer and Clayton (2017) offered three examples of civic learning goals that are grounded in democratic purposes and democratic processes both within the service learning project and as an end that builds everyone's capacities:

(a) inclusivity, which has at its core capacities to think beyond the single perspective of one's own worldview and act accordingly; (b) criticality, which has at its core capacities to recognize and challenge enshrined structural inequities that limit social justice; and (c) co-creation, which has at its core capacities to bring an assetbased orientation to collaboration and to integrate the knowledge, perspectives, and resources of all stakeholders in determining questions to be addressed, possibilities to be pursued, and strategies for collaborating effectively and with integrity. (p. 48)

\section{INTEGRATING SERVICE LEARNING WITH DIGITAL TECHNOLOGIES}

Bringle (2017) conceptualized the integration of multiple experiential pedagogies, including service learning, undergraduate research, study away, and internships as consisting of first-order (integration of two pedagogies), second-order (integration of three), or third-order (integration of four) hybrid pedagogies. In particular, he examined the combinations of pedagogies that include service learning: participatory community-action research, immersive service learning (domestic or international), and civic internships/pre-professional courses. He asserted that integration into hybrids does not necessarily improve outcomes beyond those that can be achieved through a single component pedagogy but that potential exists if the integration is thoughtfully designed and implemented. Thus, as the integration of service learning and other teaching and learning strategies that incorporate digital technologies is considered, keeping the distinctive strengths of each and intentionally merging them in accordance with clear articulation of learning goals is imperative.

Waldner, McGorry and Widener (2012) identified four ways in which the merger of service learning and technologically-supported distance education can occur, each with its unique combination of activities, products, partnerships, strengths and limitations:

Hybrid Type I (service fully on site with teaching fully online), Hybrid Type II (service fully online with teaching fully on site), Hybrid Type III (a blended format with instruction and service partially online and partially on site), and extreme e-servicelearning (100\% of the instruction and service online). (p. 133) 
Across these approaches, the authors identified several best practices related to the use of digital technologies, including assessing technical capacities as part of developing partnerships and providing needed training for all partners in the relevant technologies, coordinating synchronous and asynchronous interactions, and using collaborative online spaces that are accessible to all partners. We turn now to two sets of considerations in the integration of service learning and digital technologies, such as quality standards and instructional design.

\section{QUALITY STANDARDS}

Integrating service learning and digital technology must draw on the best of both. The discussion of service learning above suggests several defining characteristics of the pedagogy which, in turn, specify design features that lead to high quality experiences. Europe Engage listed 14 quality standards for service learning (Preradovic \& Stark, 2019):

- relevance and meaningfulness to communities and students

- valuing community organizations as partners

- reciprocity in information exchange and benefits

- shared, attainable, and assessable goals

- integration with an academic program

- encompassing civic as well as academic learning

- offering learning opportunities in communities, for everyone involved

- student collaboration in project planning and design

- guided reflection that links experience to subject matter and explores multiple perspectives

- student support from campus and community

- sufficient time

- evaluation, including by community partners

- transdisciplinary

- designed for ongoing, sustainable impact

In the U.S., service learning has been identified as a high-impact practice, one of a set of activities -- also including, for example, learning communities, first year experiences, undergraduate research, and internships -- that students report yielded deeper learning, personal growth, and practical gains. High-impact practices are presumed to share nine characteristics: they (a) are accompanied by higher expectations for student achievement, (b) result in enhanced time and effort by students, (c) produce greater student engagement with faculty and peers, (d) provide opportunities for more frequent feedback, (e) help students reflect on and integrate their learning, (f) increase students' interactions with diverse others, (g) result in the transfer of learning to other settings, (h) provide authentic ways for 
students to demonstrate their competence, and (i) result in enhanced clarity about students' educational and life goals (Kuh, 2009, 2012). Each of these qualities can be considered in designing effective service learning experiences, including when integrated with digital technologies. Kuh (2014), whose research established highimpact practices, identified four challenges to retaining these characteristics when service learning is integrated with digital technologies:

(1) tailor assignments to accommodate students' cognitive and intellectual developmental levels; (2) provide timely, constructive, personalized feedback; (3) ensure hundreds or more students effectively integrate and transfer what they are gaining from their service-learning experience; and (4) enable faculty to become confident and competent in using engaging pedagogies that make service-learning developmentally powerful. (Kuh, 2014, p. 92)

Concerning quality standards for teaching and learning that incorporates digital technologies, Reeves and Reeves (2008) identified ten dimensions (i.e., continua) to which good distance education that is web-based, online, interactive teaching and learning should attend: (a) pedagogical philosophy (instructivist vs. constructivist); (b) learning theory (behavioural vs. cognitive); (c) goal orientation (sharply focused vs. general); (d) task orientation (academic vs. authentic); (e) source of motivation (extrinsic vs. intrinsic); (f) teacher role (didactive vs. facilitative); $(\mathrm{g})$ metacognitive support (unsupported vs. integrated); (h) collaborative learning support (unsupported vs. supported); (i) cultural sensitivity (insensitive vs. sensitive); and (j) structural flexibility (fixed vs. open). These dimensions provide a basis for analyzing and improving the design, implementation, and formative and summative evaluation of online learning courses.

Produced by an international team, A Guide to Quality in Online Learning (Uvalić-Trumbić \& Daniel, n.d.) offered "several different benchmarks or quality standards [that] have been defined and tested in numerous contexts around the world." Central is "the concept of alignment, which is evident when learning objectives, measurement and assessment, educational materials, interaction and engagement of learners, and course technology work together to ensure achievement of desired learning outcomes" (p. 4). Quality Matters provides indicators of quality within eight standards, including, as examples that are explicitly linked to the use of digital technology (distinct from those that speak more generally to high quality teaching and learning): clear statements of expectations related to technical skills and etiquette for all types of communication, use of current and accessible technologies that support students as active learners, and links to technical support.

\section{INSTRUCTIONAL DESIGN}

The how's of service learning -as both a pedagogy that has as its learning goals academic and civic learning and a social change/justice strategy that brings 
all partners together as co-creators of a transformed reality- center on several key elements of design, three of which we discuss here: community partnerships, cocreation, and critical reflection. Underlying design choices in these three domains apply whether the community engaged activities are short-term or long-term; occur on campus, locally, internationally, or virtually; involve partnering with grassroots initiatives, nonprofit organizations, for-profit companies, or governmental agencies; or take the form of direct service, indirect service, research, or advocacy. Here we illustrate a few issues involved in integrating digital technologies in the context of each of these domains.

Partnerships. The nature of the community-engaged activities provides the context for the types of partnerships (face-to-face, virtual, remote) that establish the learning and change opportunities. Not just any community-based activity is compatible with learning goals that emphasize criticality, social justice, or advocacy, for example. As Boyle-Baise (2002) pointed out, "A charitable task probably will not generate insights for social change" (p. 33). Similarly, the nature of the relationships between the partners (students, community members, instructors) -- who may be proximal, distant, or virtual -- influences the ways in which and the degree to which particular learning and change goals are reached. Bringle, Clayton and Bringle (2015) noted that partnerships that "contain democratic qualities are structured in particular ways and contain particular attributes and processes (e.g., just, inclusive, participatory, equitable, reciprocal) that are critical and necessary to allowing these civic lessons to be fully developed and cognitive learning to be clarified" (p. 14). The SOFAR model posits that partnerships in service learning include relationships between and among Students, community Organization/agency staff, Faculty, campus Administrators/staff, and Residents of the community (Bringle, Clayton \& Price, 2009). The character of relationships between any of these partners can be examined, for example, with regard to communication, resource distribution, and power sharing (Clayton, Bringle, Senor, Huq \& Morrison, 2010).

Integrating service learning with digital technologies and moving beyond a faceto-face setting may have significant implications for the nature of partnerships. As one illustrative example, instructors may have concerns about the appropriateness and the quality of partnerships when students take online courses remotely. Online tools are available to support students establishing partnerships with others and can be incorporated into course design. Furthermore, new possibilities for learning and change may arise when service learning partnerships are not already established between instructors and community organizations but are co-created by students, remote from campus, in and with the communities in which they live and study. Hansen and Clayton (2014) asserted that such partnerships invite, indeed require, students to assume greater initiative, hold the potential to deepen students' sense of place and their local relationships and networks, and may lend themselves to a more democratic (with) orientation with greater student and community voice. Instructional design implications of this scenario, they suggested, include attending 
to the complexities of place-based relationships (e.g., tendencies to stereotype across difference may increase or decrease, impacts of new roles on long-standing relationships) and building in time and space mentoring that involves a high degree of student responsibility and control.

Co-creation. Intimately tied to the nature of the partnership is intentionally selecting or designing activities so that all partners engage with one another as co-educators, co-learners, and co-generators of knowledge and practice -- as cocreators of the partnership and its work (for examples of community partner perspectives on co-creation, see Clayton, 2017; Mondloch, 2009; for examples of student perspectives, see Clayton \& Stout, 2017; Zlotkowski, Longo, \& Williams, 2006). Given that the dominant mode of interactions among students, community members, faculty and staff is hierarchical and privileges the expertise of faculty and the resources of campus, developing and nurturing partnerships that are "co-" in nature requires significant capacity building among all partners and ongoing close attention to partnership dynamics.

Although integrating service learning with digital technology does not necessarily default to a technocratic norm, any tendencies toward interacting in superficial, anonymous ways and prioritizing short-term efficiencies may enhance the difficulties that regularly confront attempts to enact democratic engagement. Instructional design needs to include using digital technologies to establish a sense of group identity, deepen interpersonal relationships, and build community; facilitate multi-directional knowledge sharing and co-creation of purposes and processes; cultivate empathy and trust; and convey social presence. Examples include using online collaboration tools such as Google docs for producing written documents and communication platforms with video as well as audio capabilities; designing activities that invite sharing and celebration (e.g., telling stories, posting photographs); and establishing shared and transparent community norms and guidelines related to, for example, communicating, managing projects and processes, sharing responsibility, handling misunderstandings and conflict, and evaluating progress and outcomes.

Critical Reflection. As Bringle and Hatcher (1999) summarized, "Experience becomes educative when critically reflective thought creates new meaning and leads to growth and the ability to take informed actions" (p. 180). For all types of learning (e.g., course content, personal or professional development, civic perspectives and capacities, collaboration, research, cross-cultural dynamics, partnering with communities), it is critical reflection that taps the learning potential of the experiences. Critical reflection is a process structured around learning objectives that uses tightly aligned prompts to guide learners through inquiry that "generates learning (articulating questions, confronting bias, examining causality, contrasting theory with practice, pointing to systemic issues), deepens learning (challenging simplistic conclusions, inviting alternative perspectives, asking "why" iteratively), and documents learning (producing tangible expressions of new understandings for evaluation)" (Ash and Clayton, 2009, p. 27). The "critical" in critical reflection refers 
to both critical thinking and critical theory (e.g., attention to questions of power, privilege, and systems critique). Reflection may take varied forms (e.g., discussion, writing, embodied activity, drawing); it may take place within the parameters of a course assignment (e.g., a reflection assignment, creating and sharing an electronic portfolio) or beyond (e.g., ad hoc discussions with community members). The DEAL Model for Critical Reflection (e.g., Ash \& Clayton, 2009) supports learners in examining experiences explicitly in terms of desired learning in a way that lends itself to action and also incorporates critical thinking and higher order reasoning to both deepen inquiry and assess outcomes.

Digital technologies are, of course, prevalent in students' (and other service learning partners') lives, are widely used for communication from local to global, and are increasingly of interest among service learning practitioners as vehicles for reflection. One key consideration is that, although technology-mediated reflection need not be collaborative or shared, the use of digital technologies for reflection holds significant potential for deepening the process of meaning making by engaging the broader public with it across all of hybrid combinations identified by Waldner et al. (2012). Chang (2019) investigated collaborative reflection in online (non-service learning) courses. Particularly relevant here, given concerns about the potential for less "humanized" interactions and learning in the digital environment, he found that students identified as benefits exposure to multiple perspectives, enhanced communication skills, and reduced sense of isolation. Engaging with one another's ideas and experiences helped create, in the words of one student, "a community amongst the learners within the course and that support system can be very beneficial especially in the online environment" (p. 104). With often less explicit dynamics of power and privilege -- so visible in the face-to-face classroom -- and often with time to formulate and refine ideas, some students may feel freer not only to participate but to challenge others' ideas in virtual spaces, a key aspect of both community building and learning in virtual spaces that may transfer to face-to-face contexts as well.

Digital storytelling is an example of how reflection can be designed at the interface of service learning and digital technologies to take advantage of the benefits of public meaning making. According to Norris and colleages (2017), "In the digital world, stories can be wed with images and music, shared widely, and instantly become fodder for dialogue among individuals who may never engage with one another face-to-face. In other words, digital storytelling has the potential to be a particularly civic approach to critical reflection" (Norris, Siemers, Clayton, Weiss, \& Edwards, 2017, p. 175). Instructional design implications include ensuring an academic and critical orientation to the process (which may be counter to learner's usual approach to understanding story and to using audio-visual technologies), linking digital stories clearly to learning objectives, exploring the connections between personal experience and broader public questions and issues, experimenting with ways to convey ideas so that viewers unfamiliar with them can understand and engage with 
them, and assessing the process and the product of producing digital stories in ways that maintain academic integrity and value creativity and voice.

\section{THE CHALLENGE AND THE PROMISE OF INTEGRATING SERVICE LEARNING WITH DIGITAL TECHNOLOGIES}

As the previous section made clear, the task of integrating service learning with digital technologies can be challenging, and we do not intend to minimize the difficulties. First and foremost among potential challenges is poorly designed integration. Just as service learning is not the mere addition of a community service activity to an otherwise complete course, integrating service learning with digital technologies is not the mere addition of a community service component to a distance education course, nor is it merely relocating an existing service learning course into a virtual format supported with ICT. Integration implies the careful and intentional consideration of best practices for each educational pedagogy in ways that are aligned with learning objectives (Strait \& Sauer, 2004). Only then will enhanced educational outcomes be achieved and increased humanization of the learning environment be realized.

The design and implementation of hybrid pedagogies also faces the challenge that instructors may not be familiar with best practices for one or both of the component pedagogies. Institutional resources need to be available to optimize design and implementation. For example, many campuses in North America and a few internationally have established central service learning offices and hired staff to help instructors design, implement, and evaluate service learning courses, which is viewed as a key to advancing service learning and its institutionalization (Bringle \& Hatcher, 2000; Welch \& Saltmarsh, 2013). However, few European institutions of higher education have centralized units that can provide support for communityengaged teaching and learning or research (Meijs, Maas, \& Aramburuzabala, 2019). Analogous campus resources have been developed for distance learning to the degree that a campus is committed to expanding distance education courses (Uvalić-Trumbić \& Daniel, n.d.). Just as online instruction does not automatically mimic what can be done in the classroom, instructional designers may be needed to support instructors who are more familiar with content and less familiar with digital technology or service learning.

The role of digital technologies in service learning generates other potential concerns. When partnerships and associated service activities are virtual, there is the risk of both restricted, less fluid relationships and truncated interactions and learning opportunities. There may be technologically-based complications related to unreliability of the ICT as well as socially-based issues of unequal access to and familiarity with digital technologies.

Neither minimizing nor over-stating these challenges, we do find it meaningful to ask how service learning might be enhanced through the integration of digital 
technologies. In addition to the benefits implied above in the discussion of designing partnerships, co-creative dynamics, and critical reflection, the hybrid pedagogy may increase access to more persons, thereby democratizing participation by more and varied individuals (e.g., home-bound, non-traditional, working, rural, other nationalities). Aramburuzabala, Vargas-Moniz, Opazon, McIlrath, \& Stark (2019) noted that ICT can enhance personalization of the educational experience in service learning because it can "facilitate the delivery of learning materials to students, assessment, student tracking, collaboration and communication" (p. 236).

Teaching and learning strategies that incorporate digital technologies can be enhanced with service learning by educators designing learning experiences that focus intentionally on civic and democratic outcomes through multi-faceted partnerships, collaborative community-engaged activities, and critical reflection that is tied to a broad range of learning goals. When doing so, particular attention must be directed at guiding the identification and selection of community-engaged activities so that they align with community partners and align with academic, civic, and personal learning goals. Service learning also provides a means for making the educational experience be more constructivist, behavioral as well as cognitive, with a more general and encompassing orientation, providing authentic learning experiences, enhancing intrinsic motivation, redefining the instructor's role as a facilitator, enhancing collaborative learning within the context of distance learning, heightening cultural sensitivity to diverse others, and providing flexibility to tailor learning experiences to the interests of the learner (Reeves \& Reeves, 2008).

Research supports the capacity of well-designed service learning to enhance many of the humanizing attributes that are included in the Council of Europe's framework for democratic competences (e.g., empathy, self-efficacy, openness to others, cooperation, cultural otherness, civic-mindedness, tolerance of ambiguity). Integrating service learning with digital technologies also has the promise of enhancing many of the seven standards for improving student engagement ${ }^{2}$ in ways that humanize distance learning. These standards include empowering students as knowledge constructors, allowing students to set personal learning goals within the context of community-engaged activities, providing regular and structured reflection and feedback, learning about the responsible use of technology, expanding students' use of technology to creatively approach and contribute to civic and social issues in communities, and using collaborative technologies to improve communication skills with diverse others and examine issues from multiple perspectives.

Beyond the question of what each pedagogical innovation brings to the other, we are also intrigued with the transformational potential of the integration, especially in terms of enriching civic and humanistic ways of knowing and being. We agree with Hansen and Clayton (2014) that, far from "undermin[ing] the raison d'être" of service learning (a fear sometimes voiced by service learning practitioners who are troubled by the academy's rapid embrace of online learning), the pedagogy's integration with digital technologies "might well give us entre into an untapped set 
of possibilities for re-examining, re-conceptualizing, and re-enacting" what it is to be in partnership with and within communities, seeking to nudge the world toward shared, positive, hopeful conceptions of the good (p. 23). Here, we but begin to illustrate the transformational possibilities by revisiting notions of community and civic learning.

"Community," often used with geographic reference (as in, "local communities"), is one of the defining concepts in service learning but is too often loosely used. How can ICT and virtual environments transform the meaning of community and create additional meanings? Addressing engineers and technologists who design software and build collaborative virtual spaces, the book Online Communities (Preece, 2001) highlighted the possibilities for and necessity of holding onto community while also rethinking this important yet often trivialized concept, the "potency" of which the Internet and associated forces of commercialization may be "diluting" (p. 14). Just as community risks being reduced to referencing the collection of people and organizations that share geographic space in service learning, in the realm of digital technology it is coming to mean little more than a group of people who communicate with one another electronically. How might the integration of these two innovations help to reclaim deeper conceptions and generate new ones? Preece (2001) drew on Schuler (1996) and advocated that "new communities should combine aspects of the old and the new" (Preece, 2001, p. 19) and advised keeping "one eye on ... core values [such as equity, opportunity, creativity, and accountability, among others] while [we] strive to map human needs with technology" in the design and use of online communities (p. 19). Preece (2001) noted that "the distinction between online and face-to-face community [will increasingly] blur" (p. 20) and, if so, what new, integrative understandings and transformed conceptions of community may be possible when they are deeply engaged with the democratic values of justice, inclusivity, and co-creation from service learning? Furthermore, if individuals learn to develop strong relationships using digital technologies with individuals with whom they would otherwise never interact, then how might that carry over into a sense of connection with other people and places locally, around the world, and through time?

Educators across a wide range of student-centered pedagogies value and seek to cultivate learning communities in which they and their students all contribute to one another's learning and growth. Furthermore, change-oriented organizations around the world organize and mobilize networked communities of advocates, donors, activists, policy makers, and researchers. What new and powerful conceptions of community might arise from synthesizing their accumulated experience and wisdom when students partner with them in on-line service learning? Might the integration of service learning and digital technologies enable many more individuals, across all walks of life, to experience being co-creative members of transnational, transdisciplinary, transprofessional, transgenerational communities formed, for example, around pressing public questions and issues? 
We are similarly intrigued by the potential of this integration to generate expansive and highly nuanced conceptualizations of "civic" as a category of learning goal within and beyond higher education. What new types of civic knowledge, skill, disposition, and behavior might evolve as understandings of community transform, including both virtual as well as physical communities? What new skills and capacities are needed to be effective citizens of communities that straddle the physical and the virtual? How can virtual environments redefine civic acts, collaboration on civic issues, advocacy, and result in novel ways to contribute to social change? The integration of service learning with digital technologies may well be part of transforming notions of civic participation and associated framings of civic skills, responsibilities, rights, and duties -perhaps usefully moving beyond legalistic and geographically-bounded conceptions of what it is to be a citizen to a broader view of being an active participant in many communities, local and remote. Furthermore, this integration may be wellsuited for critically examining and clarifying the possibility of being simultaneously an active member of multiple, interacting communities within and across national borders, regardless of one's citizenship status.

\section{CONCLUSION}

We fully understand that context matters to how service learning is conceived, designed, implemented, and evaluated. Hatcher and Bringle (2012) identified macrolevel, mesolevel, and microlevel factors that constitute context. Context operates at the macrolevel because systemic, national, historical, and cultural influences shape the nature of service learning (Hatcher \& Bringle, 2012). This is wellillustrated through the examination of case studies contained in Embedding Service Learning in European Higher Education (Aramburuzabala, McIlrath, \& Opazo, 2019). Mesolevel factors operate at the level of the institution of higher education, including the institution's culture (Janke \& Domagal-Goldman, 2017), mission, leadership (Sandmann \& Plater, 2017), and infrastructure. At the microlevel, factors that influence the design and implementation of a service learning course include the discipline or professional nature of the curriculum, the values and goals that the instructor wants to emphasize by enriching a course with community-engaged activities, and relationships with community partners. At each level, European institutions of higher education face unique challenges in developing service learning (Millican et al., 2019).

How are service learning and online learning enhanced by creating hybrid courses using digital technologies? How does their integration improve learning? The science of learning has provided important guidelines for how learning occurs. For example,

What neuroscience researchers have made clear is that "the one who does the work does the learning" (Doyle, 2008). The more ways you engage with something that you are learning-such as listening, talking, reading, writing, reviewing, or thinking 
about the material or skill---the stronger the connections in your brain become and the more likely the new learning will become a more permanent memory (Doyle \& Zakrajsek, 2013, p. 7).

The successful integration of service learning and digital technologies will only fulfill its potential when the resulting hybrid pedagogy reflects these principles of learning and the principles of good practice for each of the constituent pedagogies. An important collateral activity is conducting research on the resulting hybrid course and its outcomes across multiple constituencies that include not only students but also community partners, communities, instructors, institutions, and the partnerships that support civic engagement (Clayton, Bringle, \& Hatcher, 2013a, 2013b). We strongly encourage such research in order to provide an empirical base that can support claims about the effectiveness of hybrid pedagogy in meeting intended learning objectives and improving the work.

In addition to considering the hybrid pedagogies resulting from combining service learning with digital technology, practitioners can also consider other combinations of hybrids. For example, second order hybrids integrating three pedagogies (Bringle, 2017) could include distance education courses that integrate service learning with study abroad (Whitney \& Clayton, 2011) or distance education courses that integrate service learning with internships.

We appreciate that the papers in this special issue of RIED explored how hybridization of service learning with technology, virtual environments, and distance education can contribute to civic skills, attitudes, and values within higher education; produce new approaches to learning communities and deliberative dialogue; create new platforms to support learning that are not restricted by geography; and provide new insights about learning that can have implications beyond service learning and distance learning. We implore educators to heed Singh's (2016) challenge to develop innovative pedagogical practices that enhance access to education in ways that develop social responsibility and interest in the public good.

\section{ACKNOWLEDGEMENTS}

We are grateful to Kathleen E. Edwards at the University of North Carolina at Greensboro for conversations that significantly informed this article and for supplying us to resources related to the topic.

\section{NOTAS}

1. The term we use here to encompass information and communication technologies [ICT] and virtual environments as well as distance and online learning.

2. ISTE Standards for Students, retrieved from https://www.iste.org/standard/forstudents 


\section{REFERENCES}

Aramburuzabala, P. McIlrath, L., \& Opazo, H. (2019). Embedding service learning in European higher education. New York, USA: Routledge.

Aramburuzabala, P., Vargas-Moniz, M. J., Opazo, H., McIlrath, L., \& Stark, W. (2019). Considerations for service learning in European higher education. In P. Aramburuzabala, L. McIlrath, \& H. Opazo (Eds.), Embedding service learning in European higher education (230-242). New York, USA: Routledge.

Ash, S. L., \& Clayton, P. H. (2009). Generating, deepening, and documenting learning: The power of critical reflection for applied learning. Journal of Applied Learning in Higher Education, 1, 25-48.

Battistoni, R. M. (2002). Civic engagement across the curriculum: A resource book for faculty in all disciplines. Providence, RI, USA: Campus Compact.

Battistoni, R. M. (2013). Civic learning through service learning: Conceptual frameworks and research. In P. Clayton, R. Bringle, \& J. Hatcher, (Eds.), Research on service learning: Conceptual frameworks and assessment. Vol. 2A: Faculty and students (pp. 111-132). Sterling, VA, USA: Stylus.

Brandenberger, J. (2013). Investigating personal development outcomes in service learning: Theory and research. In P. Clayton, R. Bringle, \& J. Hatcher, (Eds.), Research on service learning: Conceptual frameworks and assessment. Vol. 2A: Faculty and students (pp. 133156). Sterling, VA, USA: Stylus.

Bringle, R. G. (2017). Hybrid high-impact pedagogies: Integrating service-learning with three other high-impact pedagogies. Michigan Journal of Community Service Learning, 24(1), 49-63.

Bringle, R. G., \& Clayton, P. H. (2012). Civic education through service-learning: What, how, and why? In L. McIlrath, A. Lyons,
\& R. Munck (Eds.), Higher education and civic engagement: Comparative perspectives (101-124). New York, USA: Palgrave.

Bringle, R. G., Clayton, P. H., \& Bringle, K. E. (2015). Teaching democratic thinking is not enough: The case for democratic action. Partnerships: A Journal of Service Learning \& Civic Engagement, 6(1), 1-26. Bringle, R. G., Clayton, P. H., \& Price, M. F. (2009). Partnerships in service learning and civic engagement. Partnerships: A Journal of Service Learning \& Civic Engagement, 1(1), 1-20.

Bringle, R. G., Edwards, K. E., \& Clayton, P. H. (2014). The roots of service-learning as a means to advance the civic mission of community colleges. In A. Traver \& Z. Katz (Eds.), Service-learning at the American community college: Theoretical and empirical perspectives (13-35). New York, USA: Palgrave Macmillan.

Bringle, R. G., \& Hatcher, J. A. (1999). Reflection in service learning: Making meaning of experience. Educational Horizons, 77(4), 179-185.

Bringle, R. G., \& Hatcher, J. A. (2000). Institutionalization of service learning in higher education. Journal of Higher Education, 71, 273-290.

Celio, C. I., Durlak, J., \& Dymnicki, A. (2011). A meta-analysis of the impact of service-learning on students. Journal of Experiential Education, 34, 164-181.

Centro Latinoamericano de Aprendizaje y Servicio Solidario (CLAYSS) (n.d.a). What is "service learning"? Retrieved from http://www.clayss.org/english/ servicelearning school.html

Centro Latinoamericano de Aprendizaje y Servicio Solidario (CLAYSS) (n.d.b). The concept of service and solidarity. Retrieved from http://www.clayss.org/ english/servicelearning solidarity.html 
Chang, B. (2019). Reflection in learning. Online Learning, 23(1), 95-110.

Clayton, P. H. (2017). Community members on SLCE partnerships. Blog post. Elon, NC: Center for Engaged Learning, Elon University. Retrieved from https:// www.centerforengagedlearning. org/community-members-on-slcepartnerships/

Clayton, P. H., \& Kniffin, L. E. (2017). An introduction to service-learning and community engagement as co-inquiry. [Blog]. Elon, NC: Center for Engaged Learning, Elon University. Retrieved from http://www.centerforengagedlearning. org/an-introduction-to-service-learningand-community-engagement-as-coinquiry/

Clayton, P. H., Stokamer, S., Garvin, L., Shoemaker, E., Muse, S., \& Norvell, K. (2019). Practical wisdom on "co-" in research on service learning. In J. Hatcher, R. Bringle, \& T. Hahn (Eds.), Practical wisdom for conducting research on service learning (pp. 235-254). Sterling, VA, USA: Stylus.

Clayton, P. H., \& Stout, A. (2017, May 2). Students as co-creators of SLCE. [Blog]. Elon, NC: Center for Engaged Learning, Elon University. Retrieved from https:// www.centerforengagedlearning.org/ students-as-co-creators-of-slce/

Clayton, P. H., Bringle, R. G., \& Hatcher, J. A. (Eds.). (2013a). Research on service learning: Conceptual frameworks and assessment. Vol. 2A: Students and faculty. Sterling, VA, USA: Stylus.

Clayton, P. H., Bringle, R. G., \& Hatcher, J. A. (Eds.). (2013b). Research on service learning: Conceptual frameworks and assessment. Vol. 2B: Communities, institutions, and partnerships. Sterling, VA, USA: Stylus.

Clayton, P. H., Bringle, R. G., Senor, B., Huq, J., \& Morrison, M. (2010). Differentiating and assessing relationships in servicelearning and civic engagement: Exploitive, transactional, and transformational. Michigan Journal of Community Service Learning, 16(2), 5-21.

Conway, J. M., Amel, E. L., \& Gerwien, D. P. (2009). Teaching and learning in the social context: A meta-analysis of service learning's effects on academic, personal, social, and citizenship outcomes. Teaching of Psychology, 36, 233-245.

Council of Europe. (2016). Competences for democratic culture: Living together as equals in culturally diverse democratic societies. Strasbourg, France: Council of Europe Publishing.

Council of Europe (2017). Council of Europe reference framework of competences for democratic culture (CDC). Volume 3 - Guidance for implementation. 2. $C D C$ and pedagogy. Strasbourg, France: Council of Europe Publishing.

Deardorff, D., \& Edwards, K. E. (2013). Framing and assessing students' intercultural competence in service learning. In P. Clayton, R. Bringle, \& J. Hatcher, (Eds.), Research on service learning: Conceptual frameworks and assessment. Vol.2A: Faculty and students (157-183). Sterling, VA, USA: Stylus.

Doyle, T., \& Zakrajsek, T. (2013). The new science of learning. Sterling, VA, USA: Stylus.

Europe Engage. (n.d.). Our definition of service-learning. Retrieved from https:// europeengage.org/our-definition-ofservice-learning/

Fitch, P., Steinke, P., \& Hudson, T. (2013). Research and theoretical perspectives on cognitive outcomes of service learning. In P. Clayton, R. Bringle, \& J. Hatcher, (Eds.), Research on service learning: Conceptual frameworks and assessment. Vol. 2A: Faculty and students (57-83). Sterling, VA, USA: Stylus.

Furco, A., \& Norvell, K. (2019). What is service learning? Making sense of the pedagogy and practice. In P. Aramburuzabala, L. McIlrath, \& H. Opazo (Eds.), Embedding 
service learning in European higher education: Developing a culture of civic engagement (13-35). Oxford, UK: Routledge.

Hansen, F. B., \& Clayton, P. H. (2014). From for to of: Online service-learning as both disruption and doorway to democratic partnerships. In S. Crabill \& D. Butin (Eds.), Community engagement 2.0: Dialogues on the future of the civic in the disrupted university (12-25). New York, USA: Palgrave Macmillan.

Hatcher, J. A., \& Bringle, R. G. (2012). Exploring similarities and differences through cross-cultural comparative research. In J. Hatcher and R. Bringle (Eds.), Understanding service-learning and community engagement: Crossing boundaries through research (ix-xxii). Charlotte, NC, USA: Information Age.

Hatcher, J. A., Bringle, R. G., \& Hahn, T. W. (Eds.). (2017). Research on service learning and student civic outcomes: Conceptual frameworks and methods. Sterling, VA, USA: Stylus.

Herrero, M. A. (2017). Jornada de investigadores sobre aprendizajeservicio. Buenos Aires, Argentina: CLAYSS.

Huber, M. T., \& Hutchings, P. (2018). Foreword: Civic learning: Intersections and interactions. In M. Smith, R. Nowacek, \& J. Bernstein (Eds.), Citizenship across the curriculum (iz-xiii). Bloomington, IN, USA: Indiana University Press.

International Christian University (2009). Lessons from service-learning in Asia: Results of collaborative research in higher education. Tokyo, Japan: ServiceLearning Center, International Christian University.

Jameson, J. K., Clayton, P. H., \& Ash, S. L. (2013). Conceptualizing, assessing, and investigating academic learning in service learning. In P. Clayton, R. Bringle, \& J. Hatcher (Eds.), Research on service learning: Conceptual frameworks and assessment Vol. 2A: Students and faculty (85-110). Sterling, VA, USA: Stylus.

Janke, E. M. (2017). Organizational partnerships in service learning. In P. Clayton, R. Bringle, \& J. Hatcher (Eds.), Research on service learning: Conceptual frameworks and assessment. Volume 2B: Communities, institutions, and partnerships (573-598). Sterling, VA, USA: Stylus.

Kuh, G. D. (2009). High-impact educational practices. Washington, DC, USA: Association of American Colleges and Universities.

Kuh, G. D. (2012). A closer look at selected high-impact practices. Paper presentation at the Kentucky Council on Postsecondary Education, Louisville, KY, USA.

Kuh, G. D. (2014). Insuring that technologyenriched service-learning lives up to the promise of a high-impact activity. In S. Crabill \& D. Butin (Eds.), Community engagement 2.o: Dialogues on the future of the civic in the disrupted university (9297). New York, USA: Palgrave Macmillan.

Ma, C. H. K., \& Chan, A. C. M. (2013). A Hong Kong university first: Establishing service-learning as an academic creditbearing subject. Gateways: International Journal of Community Research and Engagement, 6, 178-198.

McIlrath, L., Aramburuzabala, P., \& Opazo, H. (2019). Introduction. In P. Aramburuzabala, L. McIlrath, \& H. Opazo (Eds.), Embedding service learning in European higher education: Developing a culture of civic engagement (1-9). Oxford, UK: Routledge.

McIlrath, L., Lyons, A., \& Munck, R. (Eds.). (2012). Higher education and civic engagement: Comparative perspectives. New York, USA: Palgrave.

McIlrath, L., \& MacLabhrainn, I. (Eds.). (2007). Higher education and civic engagement-international perspectives. Ashgate, England: Aldershot. 
Meijs,L.C.P.M.,Maas, S.A, \&Aramburuzaala, P. (2019). Institutionalisation of service learning in European higher education. In P. Aramburuzabala, L. McIlrath, \& H. Opazo (Eds.), Embedding service learning in European higher education: Developing a culture of civic engagement (213-229). New York, USA: Routledge.

Millican, J., Pollack, S., Zani, B., Stark, W., Preradovic, N. M., \& Aramburuzabala, P. (2019). The changing face of higher education: Economic and democratic imperatives. In P. Aramburuzabala, L. McIlrath, \& H. Opazo (Eds.), Embedding service learning in European higher education: Developing a culture of civic engagement (36-50). New York, USA: Routledge.

Mondloch, A. S. (2009). One director's voice. In R. Stoecker \& E. Tryon (Eds.), The unheard voices: Community organizations and service learning (136-146). Philadelphia, USA: Temple University Press.

Norris, K., Siemers, C., Clayton, P. H., Weiss, A., \& Edwards, K. E. (2017). Critical reflection and civic mindedness. (2017). In C. Dolgon, T. Eatman, \& T. Mitchell (Eds.), The Cambridge handbook of service-learning and community engagement (168-182). Boston, MA, USA: Cambridge University Press.

Novak, J. M., Markey, V., \& Allen, M. (2007). Evaluating cognitive outcomes of service learning in higher education: A metaanalysis. Communication Research Reports, 24(2), 149-157.

Preece, J. (2001). Online communities: Designing usability, supporting sociability. New York, USA: John Wiley \& Sons.

Preradovic, N. M., \& Stark, W. (2019). Identified service learning practices in European higher education. In $\mathrm{P}$. Aramburuzabala, L. McIlrath, \& H. Opazo (Eds.), Embedding service learning in European higher education: Developing a culture of civic engagement (109-131). New York, USA: Routledge.

Reeves, P. M., \& Reeves, T. C. (2008). Design considerations for online learning in health and social work education. Learning in Health and Social Care, 7(1), 46-58.

Saltmarsh, J., \& Hartley, M. (Eds.). (2012). To serve a larger purpose. Philadelphia, USA: Temple University Press.

Saltmarsh, J., Hartley, M., \& Clayton, P. H. (2009). Democratic engagement white paper. Boston, USA: New England Resource Center for Higher Education.

Sandmann, L. R., \& Plater, W. M. (2009). Research on institutional leadership for service learning. In P. Clayton, R. Bringle, \& J. Hatcher (Eds.), Research on service learning: Conceptual frameworks and assessment. Volume 2B: Communities, institutions, and partnerships (505-535). Sterling, VA, USA: Stylus.

Schuler, D. (1996). New community networks: Wired for change. Reading, MA, USA: ACM Press and Addison-Wesley.

Siemers, C., Harrison, B., Clayton, P. H., \& Stanley, T. (2015). Engaging place as partner. Michigan Journal of Community Service Learning, 22(1), 101-104.

Singh, K. (2016). Report of the Special Rapporteur on the right to education. New York, USA: United Nations Human Rights Council.

Stanton, T. K., Giles, D. E., Jr., \& Cruz, N. I. (1999). Service-learning: A movement's pioneers reflect on its origins, practice, and future. San Francisco, CA, USA: Jossey- Bass.

Stokamer, S. T., \& Clayton, P. H. (2017). Instructional design and research. In J. Hatcher, R. Bringle, \& T. Hahn (Eds.), Research on student civic outcomes in service learning: Conceptual frameworks and methods (45-65). Sterling, VA, USA: Stylus.

Strait, J., \& Sauer, T. (2004). Constructing experiential learning for online courses: 
The birth of e-service. Educause Quarterly, 1, 62-65.

Uvalić-Trumbić, S., \& Daniel, J. (n.d.). A guide to quality in online learning. Dallas, TX, USA: Academic Partnerships.

Waldner, L. S., McGorry, S. Y., \& Widener, M. C. (2012). E-service-learning: The evolution of service-learning to engage a growing online student population. Journal of Higher Education Outreach and Engagement, 16(2), 123-150.

Warren, J. L. (2012). Does service-learning increase student learning?: A metaanalysis. Michigan Journal of Community Service Learning, Spring, 56-61.

Welch, M., \& Saltmarsh, J. (2013). Current practice and infrastructures for campus centers of community engagement. Journal of Higher Education Outreach and Engagement, 17(4), 25-55.

Whitney, B. C., \& Clayton, P. H. (2011). Research on the role of reflection in international service learning. In $\mathrm{R}$.
Bringle, J. Hatcher, \& S. Jones (Eds.), International service learning: Conceptual frameworks and research (145-187). Sterling, VA, USA: Stylus.

Xing, J., \& Ma, C. (Eds.). (2010). Servicelearning in Asia: Curricular models and practices. Hong Kong, China: Hong Kong University Press.

Yorio, P. L., \& Ye, F. (2012). A meta-analysis on the effects of service-learning on the social, personal, and cognitive outcomes of learning. Academy of Management Learning \& Education, 11(1), 9-27.

Zlotkowski, E., \& Duffy, D. (2010). Two decades of community-based learning. New Directions for Teaching and Learning, 123, 33-43.

Zlotkowski, E., Longo, N., \& Williams, J. (Eds.). (2006). Students as colleagues: Expanding the circle of service-learning leadership. Providence, RI, USA: Campus Compact and Bolton, MA: Anker.

\section{ACADEMIC AND PROFESSIONAL PROFILE OF THE AUTHORS}

Robert G. Bringle. Departments of Psychology and Philanthropic Studies, Indiana University Purdue University Indianapolis.

E-mail: rbringle@iupui.edu

Patti H. Clayton. PHC Ventures and Center for Service and Learning, Indiana University Purdue University Indianapolis.

E-mail: patti.clayton@curricularengagement.com

Address:

32 Clear Vista Dr.,

Asheville, NC 18805

Date of receipt: 21/08/2019

Date of acceptance: 25/08/2019

Date of layout: 29/09/2019 